\title{
Implications for the Role of Cognate Interactions in In Vitro Human B Cell Activation by Staphylococcus aureus Cowan I and Pokeweed Mitogen
}

Noboru Suzuki, Tsuyoshi Sakane, Yuji Ueda, Yohko Murakawa, and Tokugoro Tsunematsu

Third Division, Department of Internal Medicine, Shimane Medical University, Izumo, Shimane 693, Japan

\begin{abstract}
Human B cell-triggering mechanisms were investigated using the polyclonal activators Staphylococcus aureus Cowan I (SAC) and pokeweed mitogen (PWM). When the cultures of B cells, $T$ cells, and monocytes were stimulated for $5 \mathrm{~d}$ by SAC or PWM, $B$ cells could be activated by both mitogens to proliferate and secrete Ig. Even when $T$ cells were substituted by $T$ cell-derived soluble factors, SAC-stimulated B cells could differentiate into Ig-secreting cells. In contrast, interactions of $B$ and $T$ cells for at least the first $6 \mathrm{~h}$ of culture were necessary for the $B$ cell triggering by PWM.

Experiments that allow a more precise delineation of the $B$ cell-triggering mechanisms by PWM demonstrated that interactions of $B$ cells with $\mathrm{T4}^{+}$but not $\mathrm{T8}^{+}$cells are required for the $B$ cell triggering; anti-Ia or anti-T4 antibody can block this triggering; in contrast, anti-T3 or anti-T8 antibody do not exert any effects on the $B$ cell triggering. However, all these monoclonal antibodies could not modulate the ability of $B$ cells that had been already activated by PWM to respond to $T$ cell-derived factors. These data suggest that SAC can directly activate B cells, while cognate interactions between Ia-like antigens on $B$ cells and $\mathrm{T4}^{+}$ cells are essential for B cell triggering by PWM. Furthermore, once $B$ cells are triggered, they will proliferate, differentiate, and secrete $\mathrm{Ig}$ in response to $\mathrm{T}$ cell-derived factors; Ia-like antigens or $\mathbf{T}$ cell differentiation antigens may not be involved in the processes in this cascade.
\end{abstract}

\section{Introduction}

Recent studies of the events leading to B cell activation, proliferation, and differentiation have documented that occupancy of membrane-bound Ig by antigen and/or cognate $\mathrm{T}$ cell interactions involving the Ia antigens of resting $B$ cells results in functional expression of receptors for $\mathrm{T}$ cell-derived soluble factors, and that it is these factors that in turn stimulate B cells to proliferate and differentiate into cells secreting $\operatorname{Ig}(1-5)$. Many studies regarding human $B$ cells have used polyclonal B cell activators. These polyclonal activators include mitogens such as a $\mathrm{T}$ cellindependent pure B cell mitogen Staphylococcus aureus Cowan

A preliminary report of this study was presented at the 69th annual meeting of the Federation of American Societies for Experimental Biology, April 1985, Anaheim, CA.

Address all correspondence and reprint requests to Dr. Tsuyoshi Sakane, Third Division, Department of Internal Medicine, Shimane Medical University, Izumo, Shimane 693, Japan.

Received for publication 18 June 1985.

J. Clin. Invest.

(c) The American Society for Clinical Investigation, Inc.

0021-9738/86/01/0294/07 \$1.00

Volume 77, January 1986, 294-300
I (SAC) ${ }^{1}$ that directly acts on B cells by cross-linking of the Ig receptors on their surfaces and anti-Ig antibody that interacts with the B cell surface Ig. The results of studies with these polyclonal activators suggest that SAC or a high concentration of anti-Ig antibody directly induces the proliferation of resting human B cells, while a less powerful surface-membrane Ig-mediated signal, such as that delivered by low concentrations of anti-Ig antibody, results in the activation of B cells without subsequent proliferation. However, the induction of proliferation by these activated B cells can occur in the presence of B cell stimulatory factors (BSF) (5-10). Moreover, the proliferating B cells that have been activated by SAC, a high concentration of anti-Ig antibody, or low concentrations of anti-Ig antibody plus BSF, can in turn be induced to differentiate into Ig-secreting cells by B cell differentiation factors (BCDF) (5-10).

Many of the great advances in our understanding of the regulatory mechanisms that control human Ig synthesis have emerged from studies that have used another polyclonal activator, pokeweed mitogen (PWM) (11-15). PWM is a T celldependent $\mathrm{T}$ cell and $\mathrm{B}$ cell mitogen and induces proliferation and differentiation of $\mathbf{B}$ cells into Ig-secreting cells under the adequate help of $T$ cells $(11,15)$. In the present study, we have addressed the question of whether some differences exist in the B cell-triggering mechanisms by SAC and PWM. We have also investigated the role of interactions of Ia-like antigens on $B$ cells with $\mathrm{T} 4$ antigens on $\mathrm{T}^{+}$cells in the $\mathrm{B}$ cell-triggering mechanisms by mitogens. Our results clearly delineate that SAC stimulation of resting $B$ cells results by itself in functional expression of receptors for $T$ cell-derived soluble factors and that cognate $T$ cell interactions involving the Ia-like antigens of $B$ cells are required for the induction of B cells to express such functional receptors by PWM.

\section{Methods}

Cell separations. Peripheral blood mononuclear cells from healthy volunteer donors were separated into $T$ cells and non- $T$ cells by means of a sheep red blood cell (SRBC)-rosette technique. The rosetted $\mathrm{T}$ cells were further fractionated into $\mathrm{T}$ cell subsets, $\mathrm{T}^{+}$and $\mathrm{T} 8^{+}$, by complement-mediated cell lysis with monoclonal antibodies OKT8 and OKT4 (Ortho Pharmaceutical Corp., Raritan, NJ), respectively. Analysis of the T cell subpopulations showed that the OKT8-treated population yielded $>94 \% \mathrm{~T}^{+}$cells and $<1 \% \mathrm{~T}^{+}$cells, whereas the OKT4-treated population contained $>96 \% \mathrm{~T}^{+}$cells and $<2 \% \mathrm{~T}^{+}$cells. B cells and monocytes were obtained from the unrosetted non-T cell fraction as follows: B cells were obtained by further depletion of $T$ cells remaining in the non- $T$ cell fraction by complement-mediated cell lysis with OKT3 antibody (Ortho Pharmaceutical Corp.). This was followed by depletion of mono-

1. Abbreviations used in this paper: $\mathrm{BCDF}, \mathrm{B}$ cell differentiation factors; BSF, B cell stimulatory factors; Con A, concanavalin A; IL-2, interleukin 2; MHC, major histocompatibility complexes; PFC, plaque-forming cell; PHA, phytohemagglutinin; PWM, pokeweed mitogen; SAC, Staphylococcus aureus Cowan I; SRBC, sheep red blood cell. 
cytes by removal of cells adhering to petri dishes and by complementmediated cell lysis with OKM1 antibody (Ortho Pharmaceutical Corp.). The resultant B cell population contained no $\mathrm{T}$ cells, $<0.2 \%$ monocytes, and $>90 \%$ cells bearing surface-membrane Ig. Moreover, the B cells obtained did not respond at all to phytohemagglutinin (PHA; Wellcome Research Laboratories, Beckenham, England) and concanavalin A (Con A; Pharmacia Fine Chemicals, Piscataway, NJ) at their optimal concentrations. Monocytes were obtained by collecting the cells adhering firmly to petri dishes. All these purification procedures were repeated twice and have been described in detail elsewhere (16-18).

Preparation of partially purified T cell-derived soluble factors. Fresh, pooled human peripheral mononuclear cells $\left(2.5 \times 10^{6} / \mathrm{ml}\right)$ were stimulated for $48 \mathrm{~h}$ with PHA $(1 \mu \mathrm{g} / \mathrm{ml})$. The supernatants were collected, purified by several chromatographic steps as described elsewhere $(19$, 20), and were designated partially purified $T$ cell-derived soluble factors. The characterization of the factors obtained has been described previously (18-20). The factors obtained had neither PHA activity nor interferon $\gamma$ activity; they contained BSF activity and BCDF activity as well as interleukin 2 (IL-2) activity.

Overall experimental design. Activated B cells were generated by PWM stimulation in a first culture for $6 \mathrm{~h}$. These cells were washed four times to remove PWM, and further incubated in the presence of partially purified $T$ cell-derived soluble factors in a second culture. After incubation of $5 \mathrm{~d}$ in the second culture, cells were assayed either for their proliferative responses or for their plaque-forming cell (PFC) responses. In all studies, $\mathrm{T}$ cells and monocytes to be used in the first culture were obtained from the same normal donor who provided B cells.

Generation of activated $B$ cells by stimulation with $P W M$ (first culture). $5 \times 10^{6} \mathrm{~B}$ cells, $5 \times 10^{6} \mathrm{~T}$ cells, and $5 \times 10^{5}$ monocytes were incubated in 4-ml culture medium, RPMI 1640 (FLow Laboratories Inc., McLean, VA) supplemented with $10 \%$ fetal bovine serum (Flow Laboratories Inc.) with $4 \mu \mathrm{g}$ PWM (PWM-activated B cells), or without PWM (unactivated control $\mathrm{B}$ cells) at $37^{\circ} \mathrm{C}$ in a humidified $5 \% \mathrm{CO}_{2} / 95 \%$ air environment. $6 \mathrm{~h}$ later, the cells were harvested, washed four times, and B cells were isolated exactly as described above. These B cells were then incubated in a second culture (see below).

The basic first culture system was then perturbed by a number of different procedures. In some experiments, unfractionated $T$ cells were substituted by $\mathrm{T}^{+}$or $\mathrm{T}^{+}$cells. Anti-Ia, anti-T3, anti-T4, or anti-T8 monoclonal antibody (Coulter Diagnostics, Coulter Electronics, Inc., Hialeah, FL) was also added to the first culture at a final concentration of $25 \mu \mathrm{g} / \mathrm{ml}$ to investigate the influence of the respective monoclonal antibodies on the B cell-triggering mechanisms. Our preliminary experiments revealed that addition of $25 \mu \mathrm{g} / \mathrm{ml}$ anti-T3 antibody at the initiation of culture resulted in complete abrogation of either PHA responses, Con A responses, or autologous and allogeneic mixed lymphocyte reactions by $\mathrm{T}$ cells. In addition, anti-T3 antibody at the above concentration could not induce $\mathrm{T}$ cell-proliferative responses at all. In other experiments, $5 \times 10^{5}$ monocytes were added to $1 \times 10^{7} \mathrm{~B}$ or T cells and each was individually prestimulated for 6 or $24 \mathrm{~h}$ with $1 \mu \mathrm{g} /$ $\mathrm{ml}$ of PWM. Thereafter, the individually prestimulated lymphocytes were washed extensively. The individually prestimulated $T$ cells and individually prestimulated $B$ cells, or individually prestimulated $T$ cells and fresh B cells, or individually prestimulated B cells and fresh $T$ cells, or fresh $T$ cells and fresh $B$ cells were paired and subjected to a first culture for $6 \mathrm{~h}$ in the presence or absence of PWM. B cells were then isolated from such first cultures and added to the second assay culture systems. Fresh lymphocytes to be used here were obtained 6 or $24 \mathrm{~h}$ later from a new bleeding of the same normal individual who originally provided the individually prestimulated lymphocytes. Purified fresh T cells and B cells that were paired with the individually prestimulated lymphocytes were prepared exactly as described above.

Assay for proliferative responses by $P W M$-activated B cells in a second culture. In order to examine proliferative responses of PWM-activated B cells in the first culture, a second culture was performed in 96-well, round-bottomed microtiter plates (Costar Data Packaging Corp., Cambridge, MA). Each culture contained $5 \times 10^{4} \mathrm{PWM}$-activated or unactivated control B cells from the first culture and $25 \%$ (vol/vol) of partially purified T cell-derived soluble factors. All cultures were performed in a total volume of $200 \mu \mathrm{l}$ and were harvested on day 5 . Proliferative responses were measured by the incorporation of $\left[\right.$ methyl $\left.-{ }^{3} \mathrm{H}\right]$ thymidine $(5 \mathrm{Ci} /$ mmol; Amersham Corp., Arlington Heights, IL) over the last $20 \mathrm{~h}$ of the culture.

Assay for PFC responses by PWM-activated B cells in a second culture. The second culture to induce Ig-secreting cells was established in a 1-ml vol in $12 \times 75 \mathrm{~mm}$ plastic tubes (Falcon Labware Div., Becton-Dickinson \& Co., Oxnard, CA) with $2 \times 10^{5} \mathrm{PWM}$-activated or unactivated control $B$ cells from the first culture and $400 \mu$ partially purified $T$ cell-derived soluble factors. After $5 \mathrm{~d}$ culture in $5 \% \mathrm{CO}_{2}$ in a humidified air atmosphere, cells were harvested, washed three times in balanced salt solution, and then assayed for their PFC responses.

When B cells were activated by PWM, IgG + IgA + IgM-producing cells were detected in a reverse hemolytic PFC assay $(14,16,21)$ in almost all experiments. When B cells were stimulated with SAC, IgM secretion by B cells was measured with the reverse hemolytic PFC assay. This was done because the Ig binding characteristics of Staphylococcal protein A that SAC would display in an insoluble form to act, at least in part, as B cell activators, might interfere with reverse hemolytic PFC assay for IgG-producing cells (22). Hemolytic plaques were enumerated in triplicate and the results were expressed as the mean $\mathrm{PFC} / 10^{6} \mathrm{~B}$ cells in the original culture.

\section{Results}

Requirement of T-B cell interactions for Ig production of PWMbut not $S A C$-stimulated $B$ cells. To determine whether direct $T$-B cell interactions are needed for human $B$ cells to be activated by SAC or PWM to maturate into Ig-secreting cells, or alternatively, to determine whether $\mathrm{T}$ cell-derived soluble factors could be substituted for $\mathrm{T}$ cells, $B$ cells $\left(2 \times 10^{5} / \mathrm{ml}\right)$ plus monocytes $\left(2 \times 10^{4} / \mathrm{ml}\right)$ were cultured for $5 \mathrm{~d}$ with one of the polyclonal B cell activators, SAC $(0.002 \% \mathrm{vol} / \mathrm{vol})$ and PWM $(1 \mu \mathrm{g} / \mathrm{ml})$, and either T cells $\left(2 \times 10^{5} / \mathrm{ml}\right)$ or $\mathrm{T}$ cell-derived soluble factors (40\% vol/vol). Ig-secreting cells on day 5 were measured using reverse hemolytic PFC assays for IgM. As shown in Fig. 1, substantial PFC responses were observed by giving a stimulation with either SAC or PWM to a combination of B cells, T cells, and monocytes. Ig production equivalent to that in the presence of $\mathrm{T}$ cells was also observed by stimulating $\mathrm{B}$ cells and monocytes with SAC in the presence of T cell-derived soluble factors (Fig. 1). On the contrary, when PWM stimulation was given to a $B$ cell plus monocyte combination, Ig production did not occur at all, even if $\mathbf{T}$ cell-derived soluble factors were present (Fig. 1). These results indicate that the induction of Ig production by PWM requires direct interactions of $B$ cells with $T$ cells and that $\mathrm{T}$ cell-derived soluble factors cannot substitute $\mathrm{T}$ cells.

Optimal conditions for $B$ cell triggering by PWM in a first culture. To study whether the direct interactions of B cells with $T$ cells throughout the course of culture are needed to activate B cells by PWM, or alternatively, whether contact of B and T cells for only a certain period of time is sufficient, B cells, $T$ cells, and monocytes were stimulated with PWM in the first culture for various periods of time. PWM-stimulated B cells were then isolated by means of SRBC-rosetting technique, removal of cells adhering to petri dishes, and complement-mediated cell lysis using monoclonal antibodies, OKT3 and OKM1. These isolated B cells were further cultured for $5 \mathrm{~d}$ with or without $T$ cell-derived soluble factors in the second culture to induce proliferative responses and PFC responses. When the first culture was performed for $<3 \mathrm{~h}$, very few $\mathrm{PFC}$ responses were observed, even when $T$ cell-derived soluble factors were added to the second culture (Fig. 2). However, substantial PFC responses were 


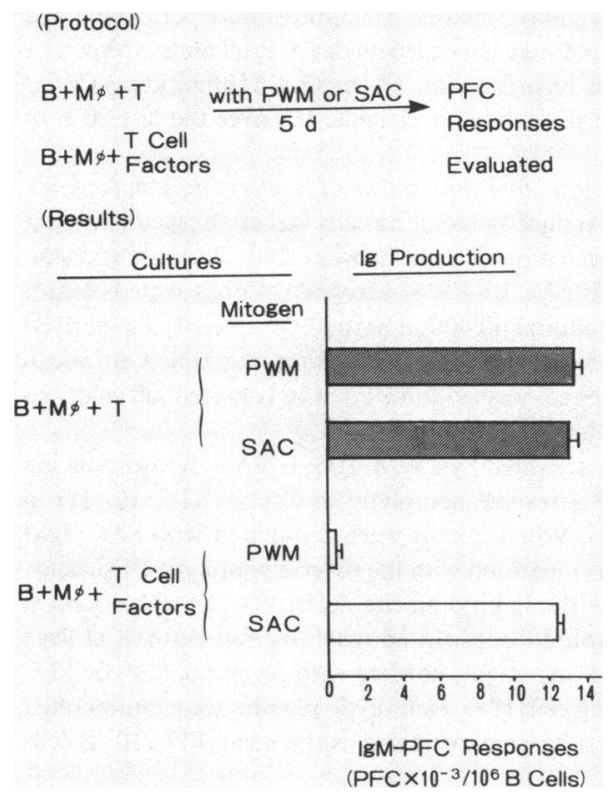

Figure 1. Requirement of T cells for PWM-induced, but not SAC-induced, Ig production: summary of the results from eight different normal donors. B cells $\left(2 \times 10^{5} / \mathrm{ml}\right)$ and monocytes $\left(2 \times 10^{4} / \mathrm{ml}\right)$ were stimulated with SAC $(0.002 \% \mathrm{vol} / \mathrm{vol})$ or PWM $(1 \mu \mathrm{g} / \mathrm{ml})$ in the presence of the following: $\mathrm{T}$, $\mathrm{T}$ cells $\left(2 \times 10^{5} / \mathrm{ml}\right)$; and $\mathrm{a}$, partially purified T cell-derived soluble factors $(40 \% \mathrm{vol} / \mathrm{vol})$. The number of cells secreting IgM was measured on day 5 using reverse hemolytic PFC assays. The mean PFC responses+SEM are shown.

induced when B cells stimulated with PWM in the first culture for more than $6 \mathrm{~h}$ were further incubated in the second culture in the presence of $T$ cell-derived factors (Fig. 2). In data not
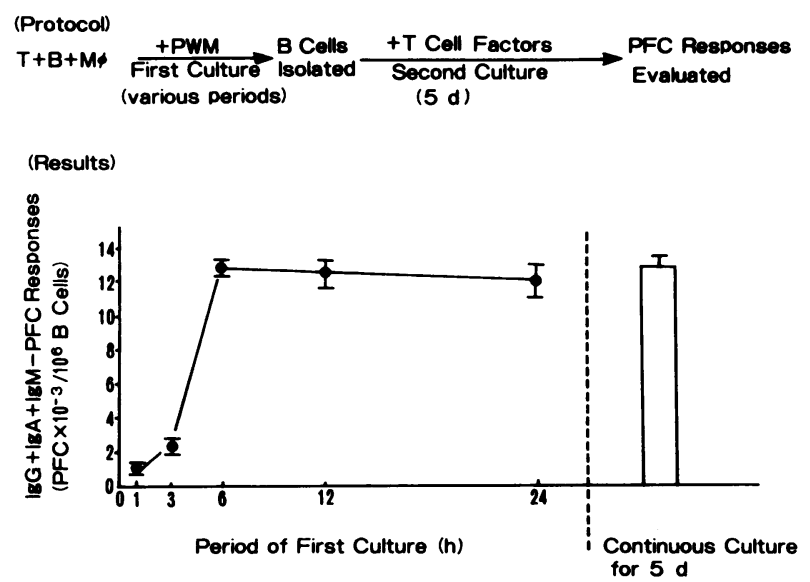

Figure 2. Necessary period of time in the direct contact of B and T cells for B cell triggering by PWM. $5 \times 10^{6} \mathrm{~B}$ cells, $5 \times 10^{6} \mathrm{~T}$ cells, and $5 \times 10^{5}$ monocytes were stimulated for various period of time with PWM $(1 \mu \mathrm{g} / \mathrm{ml})$ in the first culture. B cells were then isolated from the first culture by means of SRBC-rosetting technique, removal of cells adhering to petri dishes, and complement-mediated cell lysis using OKT3 and OKM1 monoclonal antibodies. The isolated B cells $\left(2 \times 10^{5} / \mathrm{ml}\right)$ were further incubated with $\mathrm{T}$ cell-derived soluble factors $(40 \% \mathrm{vol} / \mathrm{vol})$ in the second culture. Cells secreting IgG + IgA + IgM were enumerated on day 5 by reverse hemolytic PFC assays. Data represent the mean PFC responses \pm SEM of four separate experiments using cells from four different normal donors. shown, substantial proliferation in the second culture was also obtained from B cells stimulated with PWM for $\geq 6 \mathrm{~h}$ but not for $<3 \mathrm{~h}$ in the first culture. The results indicate that only direct contact of $B$ and $T$ cells for a certain period of culture is sufficient for the B cell triggering by PWM.

The next investigation was concerned with whether B cells are activated only in the coexistence of $B$ cells, $T$ cells, and PWM or whether B cells are activated and become sensitive to $T$ cell-derived factors even when the first culture is established using B and T cells individually prestimulated by PWM. To this end, individually prestimulated $B$ and $T$ cells were prepared by stimulating B cells plus monocytes and $T$ cells plus monocytes with PWM separately for $6 \mathrm{~h}$. These individually prestimulated $\mathrm{B}$ and $\mathrm{T}$ cells, or individually prestimulated $\mathrm{B}$ or $\mathrm{T}$ cells and autologous fresh T or B cells were combined, incubated for $6 \mathrm{~h}$ in the presence or absence of PWM (first culture), and then B cells were isolated for the second culture containing $T$ cell-derived factors. As shown in Fig. 3, only small PFC responses were observed when PWM was not present in the first culture of any of the combinations of individually prestimulated $B$ plus $T$ cells, individually prestimulated $B$ cells plus fresh $T$ cells, individually prestimulated T cells plus fresh B cells, and fresh B and T cells. However, when PWM was present in the first culture, substantial PFC responses could be induced in any of the combinations of individually prestimulated lymphocytes and/or fresh lymphocytes. Similar results were also obtained even when either T or $B$ cells were individually prestimulated for $24 \mathrm{~h}$ with PWM. This indicates that B cell triggering by PWM does not occur even if individually prestimulated $B$ and $T$ cells coexist, but does occur only when B and T cells and PWM coexist.

$T$ cell subsets involved in B cell triggering by $P W M$. To identify $T$ cell subsets involved in the B cell triggering by PWM, B cell plus monocyte combinations added either with $\mathrm{T}^{+}$or $\mathrm{T}^{+}$ cells were stimulated with PWM for $6 \mathrm{~h}$ in the first culture. Thereafter, B cells were isolated from the first culture and further incubated in the second culture for $5 \mathrm{~d}$ in the presence of $\mathrm{T}$ cellderived soluble factors. As shown in Fig. 4, B cells cultured with $\mathrm{T}^{+}$cells in the first culture showed vigorous proliferative responses and PFC responses by reacting to $T$ cell-derived soluble factors in the second culture. However, B cells incubated with $\mathrm{T}^{+}$cells in the first culture poorly responded in both proliferation and $\mathrm{Ig}$ production even if $\mathrm{T}$ cell-derived factors were present in the second culture. These results indicate that B cell triggering by PWM occurs only when $\mathrm{T4}^{+}$, but not $\mathrm{T}^{+}$, cells are in direct interactions with $B$ cells. The results presented here also suggest the possibility of $B$ cell activation occurring through the interaction of T4 antigens on T cells and Ia-like antigens on $B$ lymphocytes and/or monocytes, since T4 antigens are receptors that recognize class II antigens of the major histocompatibility complexes (MHC) (23).

Modulation by a series of monoclonal antibodies of $B$ cell triggering by PWM. Anti-Ia, anti-T3, anti-T4, and anti-T8 antibodies were added to the first culture of $B$ cells, $T$ cells, monocytes, and PWM to examine the ability of the individual antibodies to modulate the mechanisms of B cell triggering (Fig. 5). When the first culture was performed in the presence of antiIa or anti-T4 antibody, proliferative as well as PFC responses induced in the second culture were remarkably decreased. However, when anti-T3 and anti-T8 antibodies were added to the first culture, both of the responses in the second culture were not inhibited at all. These results strongly support the above hypothesis that T4 antigens on T cells and Ia-like antigens on 


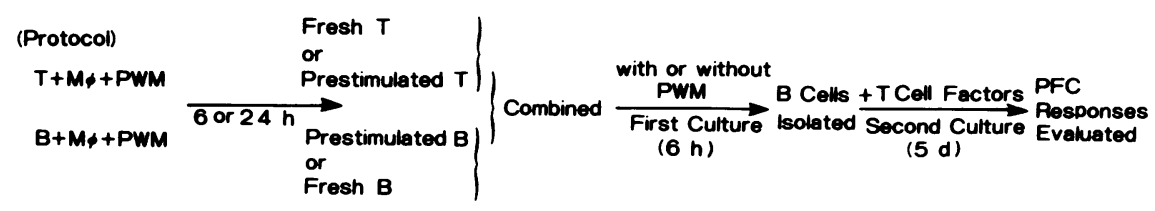

(Results)

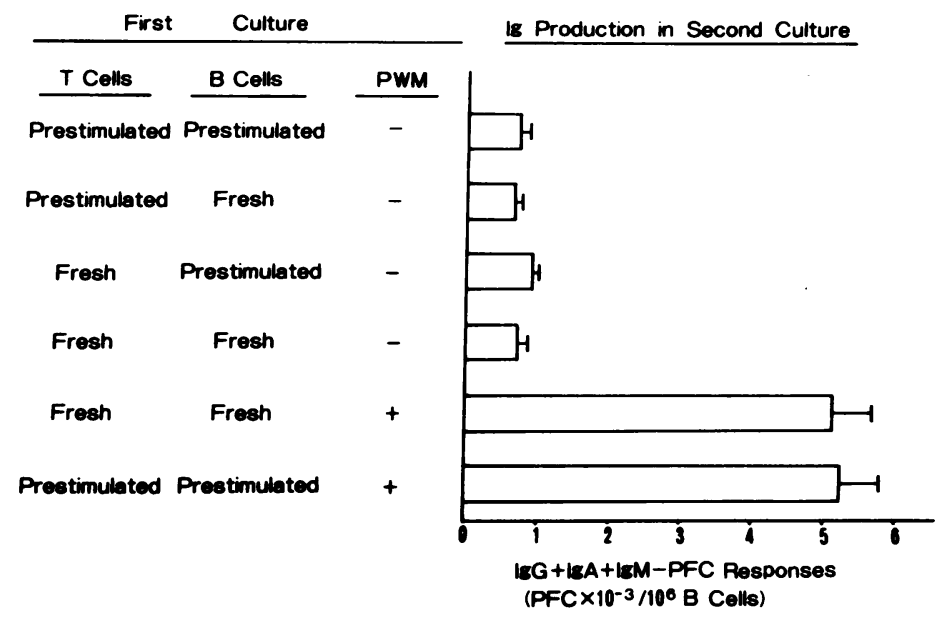

Figure 3. Requirement of the coexistence of $B$ cells, $T$ cells, and PWM for $B$ cell triggering by PWM. $1 \times 10^{7} \mathrm{~T}$ or B cells together with 5 $\times 10^{5}$ monocytes were individually prestimulated for $6 \mathrm{~h}$ with $1 \mu \mathrm{g} / \mathrm{ml} \mathrm{PWM}$. The cells were then washed four times to remove PWM. Either the individually prestimulated $\mathrm{T}$ cells and individually prestimulated B cells, individually prestimulated $T$ cells and fresh B cells, fresh $T$ cells and individually prestimulated $B$ cells, or fresh $T$ cells and fresh $B$ cells were paired and incubated for $6 \mathrm{~h}$ with or without PWM in the first culture. Fresh T and B cells to be used in the first culture were obtained $6 \mathrm{~h}$ later from a new bleeding from the same normal individuals who originally provided the individually prestimulated lymphocytes. Thereafter the B cells were isolated and further incubated in the second culture in the presence of $T$ cell-derived soluble factors. The number of cells secreting IgG + IgA + IgM was measured on day 5 using reverse hemolytic PFC assays. Data represent the mean PFC responses+SEM of four separate experiments using four different normal donors.
non-T cells or possibly B cells are involved in B cell-triggering mechanisms by PWM.

Effect of various monoclonal antibodies in the second culture. $B$ cells, $T$ cells, and monocytes were incubated with PWM for $6 \mathrm{~h}$ in the first culture and B cells were then isolated. Anti-Ia, anti-T3, anti-T4, anti-T8, or anti-Tac antibodies were added to the second culture of the B cells isolated from the first culture plus $T$ cell-derived soluble factors to examine the influence of these individual antibodies in the second culture on the proliferative and PFC responses. As shown in Fig. 6, even if these various monoclonal antibodies were added to the second culture, once activated, B cells responded to $T$ cell-derived factors sufficiently, and their proliferation and Ig production were not inhibited by the monoclonal antibodies.

\section{Discussion}

SAC can directly activate and induce a degree of proliferation of resting human B cells by cross-linking of the $\mathrm{Ig}$ receptors on $B$ cell surfaces without requirement for the process of self rec-
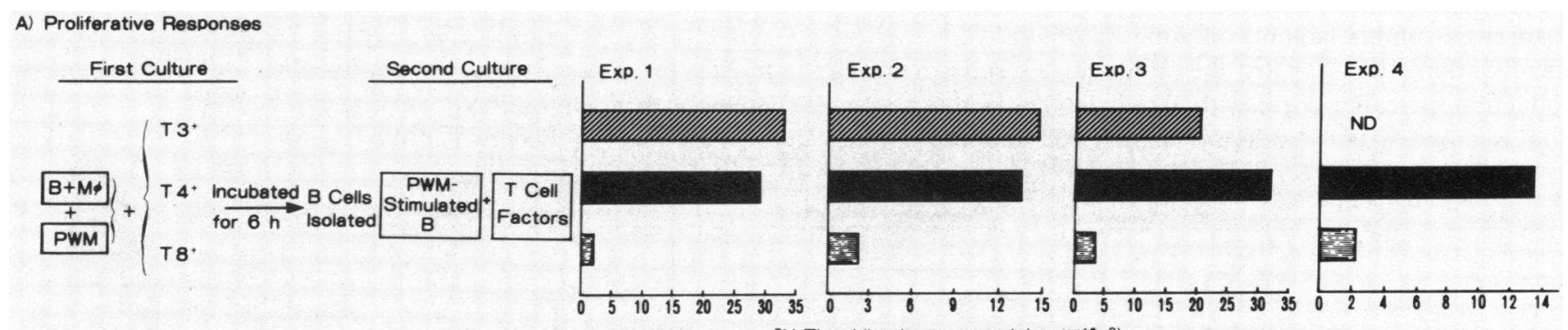

B) Is Production
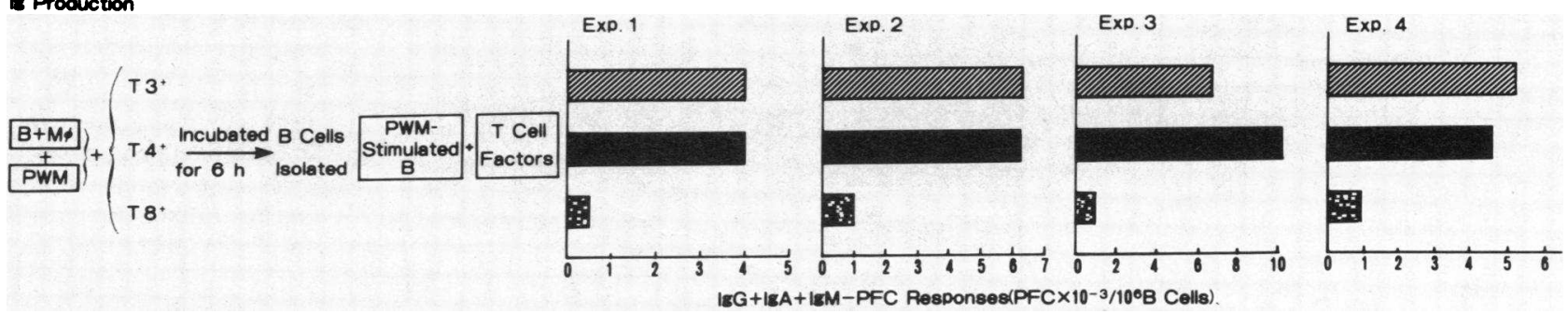

Figure 4. Requirement of $\mathrm{T}^{+}$, but not $\mathrm{T}^{+}$, cells for $\mathrm{B}$ cell triggering by PWM. $5 \times 10^{6}$ B cells and $5 \times 10^{5}$ monocytes were incubated for 6 $\mathrm{h}$ with $1 \mu \mathrm{g} / \mathrm{ml}$ PWM in the presence of the following: $\mathrm{m}, 5 \times 10^{6} \mathrm{~T}^{+}$ cells; $\mathrm{a}, 5 \times 10^{6} \mathrm{~T}^{+}$cells; and $\mathrm{a}, 5 \times 10^{6} \mathrm{~T}^{+}$cells (first culture). The $B$ cells were then isolated from the first culture and further incubated for $5 \mathrm{~d}$ with partially purified $\mathrm{T}$ cell-derived soluble factors in the sec-

ond culture. Proliferative responses were measured by incorporation of $\left[{ }^{3} \mathrm{H}\right]$ thymidine during the last $20 \mathrm{~h}$ of the second culture. Cells secreting IgG + IgA + IgM were measured by reverse hemolytic PFC assays. Similar results were obtained from three additional experiments. 


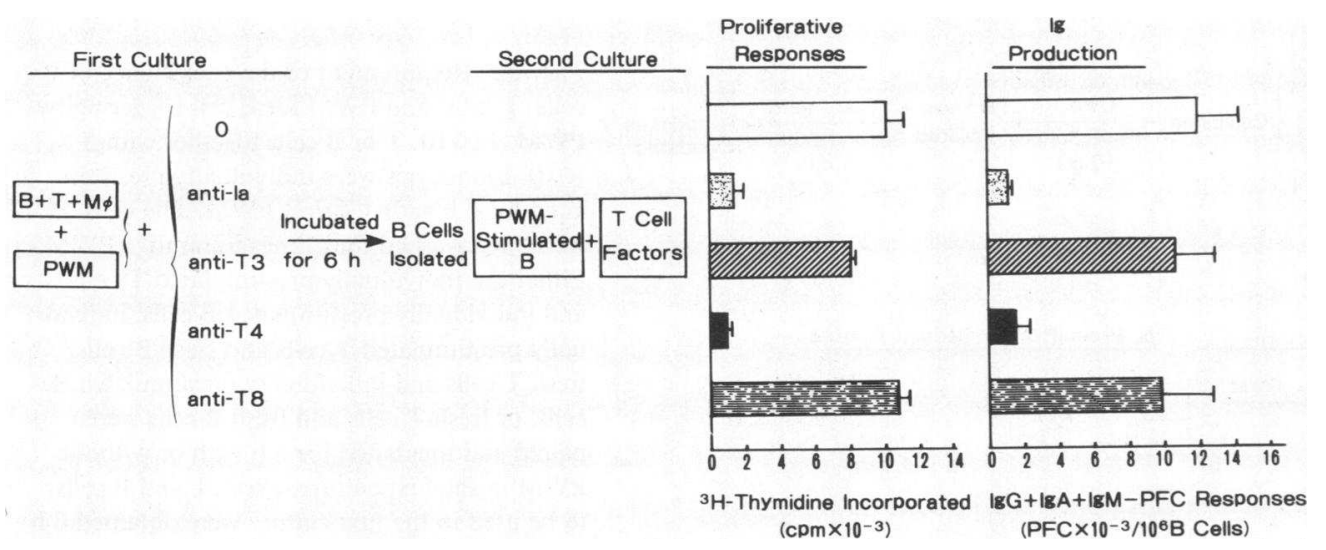

Figure 5. Effect of addition of a series of monoclonal antibodies to the first culture on the $B$ cell triggering by PWM. $5 \times 10^{6} \mathrm{~B}$ cells, $5 \times 10^{6} \mathrm{~T}$ cells plus $5 \times 10^{5}$ monocytes were stimulated for 6 $\mathrm{h}$ with $1 \mu \mathrm{g} / \mathrm{ml} \mathrm{PWM}$ in the first culture in the presence of the following: $\square$, medium; $\pi, 25 \mu \mathrm{g} / \mathrm{ml}$ anti-Ia-like antibody; $\mathrm{m}, 25 \mu \mathrm{g} /$ $\mathrm{ml}$ anti-T3 antibody; $\mathrm{m}, 25 \mu \mathrm{g} / \mathrm{ml}$ anti-T4 antibody; and $\mathrm{e}, 25 \mu \mathrm{g} /$ $\mathrm{ml}$ anti-T8 antibody. The B cells were then isolated and further incubated for $5 \mathrm{~d}$ in the second culture in the presence of $T$ cellderived soluble factors. Proliferative responses were measured by incorporation of $\left[{ }^{3} \mathrm{H}\right]$ thymidine during the last $20 \mathrm{~h}$ of the second culture. Cells producing IgG + IgA + IgM were measured by reverse hemolytic PFC assays. Data represent the mean responses+SEM of 10 separate experiments using cells from 10 different normal donors.

ognition through the interaction of $T$ and $B$ cells (7). Moreover, when $T$ cell-derived soluble factors including IL-2, BSF, and BCDF coexist, a proliferative state of the SAC-stimulated B cells is much enhanced and sustained. In addition, these cells can be further induced to differentiate into Ig-secreting cells $(8,18)$. On the other hand, PWM activates B cells and induces their proliferation and Ig production if combined with adequate help of $\mathrm{T}$ cells (11). Our results also support the above results well. We have further extended those results to elucidate not only the precise $B$ cell-triggering mechanisms but also complete activation mechanisms that drive a cell through proliferation as well as differentiation by PWM. We have demonstrated that the B cell triggering by PWM occurs through the interactions of B cells and $\mathrm{T}^{+}$cells, and that effective interactions occur only when the three are in direct contact. It was also clarified that the interactions occurring between $T$ and $B$ cells rest upon the recognition by $\mathrm{T}^{+}$cells of the Ia-like antigens on $\mathrm{B}$ cells and/or monocytes, that once B cells are triggered by PWM through such interactions, these activated cells become sensitive to $T$ cell-derived soluble factors containing proliferative as well as differentiation signals, so that the proliferative responses and $\mathrm{Ig}$ production thereafter occur with $\mathrm{T}$ cell-derived factors alone.

It is known that $\mathrm{T}^{+}$cells are major $\mathrm{T}$ cell subsets that func- tion as helper cells in the PWM-stimulated Ig production system $(12,13) . \mathrm{T}^{+}$cell plus $\mathrm{B}$ cell combinations induce much more Ig production than do $\mathrm{T}^{+}$cell plus $\mathrm{B}$ cell combinations (12, 13). We have provided evidence that the difference in helper activity between $\mathrm{T}^{+}$and $\mathrm{T} 8^{+}$cells is also observed in the $\mathrm{B}$ cell-triggering phase and that only $B$ cells in intimate contact with $\mathrm{T}^{+}$cells are triggered and reach the proliferation and differentiation phases in the cascade of $B$ cell-activation mechanisms. Suppressor or cytotoxic cells are mainly distributed in $\mathrm{T}^{+}$cells (13). To maturate into effector cells of their precursors, $\mathrm{T}^{+}$precursors must go through the interactions with $\mathrm{T}^{+}$cells that bear the function as inducer cells $(15,24)$. Therefore, the failure of $\mathrm{B}$ cell activation in the $\mathrm{T}^{+}$cell plus $\mathrm{B}$ cell combinations could be due to the failure of $\mathrm{T}^{+}$cells to recognize $\mathrm{B}$ cells rather than to the suppressor or cytotoxic effect of $\mathrm{T} 8^{+}$cells. Difference in helper activity between $\mathrm{T}^{+}$and $\mathrm{T}^{+}$cells would also be expected to exist in the differential ability to produce $T$ cell-derived soluble factors. In this regard, our preliminary experiments revealed that $\mathrm{PWM}$-stimulated $\mathrm{T}^{+}$and $\mathrm{T}^{+}$cells produced equally active IL-2, BSF, and BCDF activities, suggesting that the difference in helper activity between the $\mathrm{T}^{+}$and $\mathrm{T}^{+}$subsets is mainly dependent on the B cell-triggering levels.

A series of monoclonal antibodies directed at differentiation
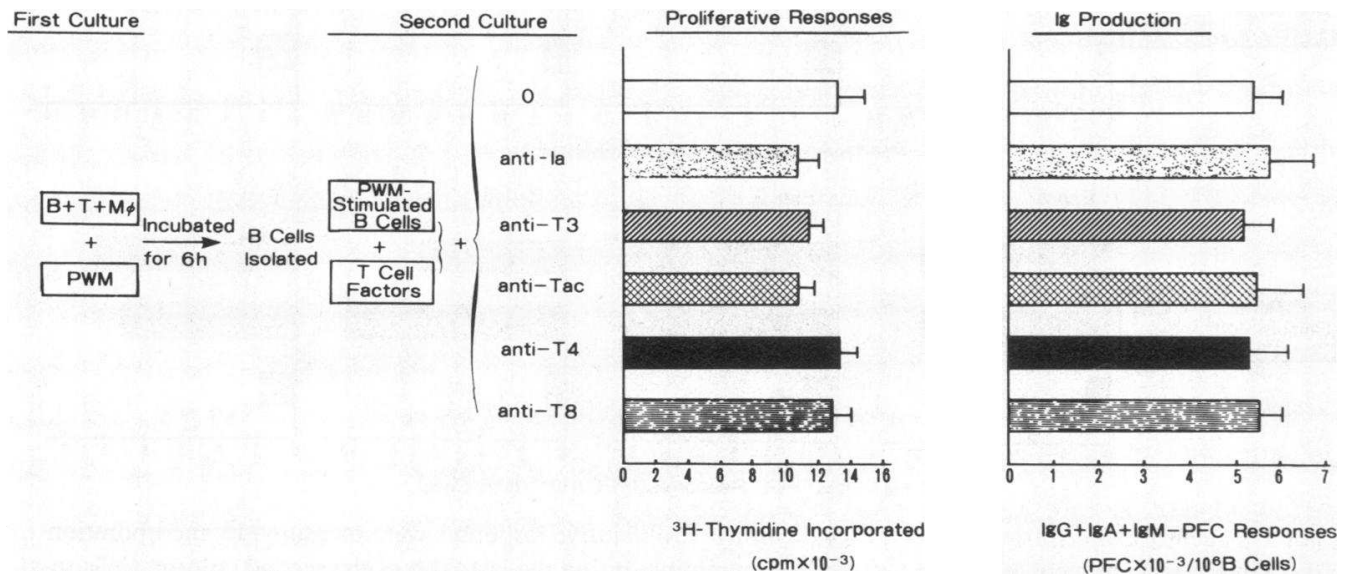

Figure 6. Effect of addition of a series of monoclonal antibodies to the second culture on the proliferation and differentiation of $B$ cells that have been already triggered by PWM. B cells were first activated for $6 \mathrm{~h}$ with PWM in the first culture in the presence of $T$ cells and monocytes. B cells isolated from the first culture were further incubated for $5 \mathrm{~d}$ with $\mathrm{T}$ cellderived soluble factors in the second culture in the presence of the following: $\square$, medium; $\mathrm{E}, 25 \mu \mathrm{g} / \mathrm{ml}$ anti-la an-

tibody; $25 \mu \mathrm{g} / \mathrm{ml}$ anti-T3 antibody; $\mathrm{n}$, anti-Tac ascites at a final dilution of 1:1,000; $\mathrm{n}, 25 \mu \mathrm{g} / \mathrm{ml}$ anti-T4 antibody; and $\mathrm{n}, 25 \mu \mathrm{g} / \mathrm{ml}$ anti-T8 antibody. Proliferative responses were measured by incorporation of $\left[{ }^{3} \mathrm{H}\right]$ thymidine during the last $20 \mathrm{~h}$ of the second culture. Cells secreting IgG + IgA + IgM were measured by reverse hemolytic PFC assays. Data represent the mean responses+SEM of eight separate experiments using cells from eight different normal donors. 
antigens on $\mathrm{T}$ or $\mathrm{B}$ lymphocyte surfaces have been used in recent years in the analysis of the role of these antigens in a complex series of immune responses. Monoclonal antibodies against T4 antigens, for instance, are known to selectively inhibit the helper activity or cytotoxic activity of $\mathrm{T}^{+}$cells $(25,26)$. It is also known that $\mathrm{T} 4$ antigens play an important role in lymphokine production, helper activity, or cellular interactions by which the proliferation and Ig production can be induced either in autologous mixed lymphocyte reactions or antigen-specific systems (27-29). Monoclonal antibodies against T8 antigens selectively interfere with the suppressor activity or cytotoxic activity of $\mathrm{T}^{+}$cells $(25,26)$. More recently, it has been further found that T4 and T8 antigens do recognize and respond to MHC antigens, T4 molecules bind to a constant region of a class II MHC gene product, and T8 antigens represent receptors for a constant region of a class I MHC gene product (23). On the other hand, the antibodies against T3 antigens not only act on T cells and induce their proliferation $(30,31)$ but also act to suppress functional maturation of $T$ cells after antigenic stimulation $(25,32)$ as well as to inhibit the development of effector functions of cloned $\mathrm{T}$ cells (33). The antibodies against Ia-like antigens are also known to suppress both cellular immunity and humoral immunity well $(4,34,35)$.

Our results also revealed suppressive effects by anti-Ia-like antibodies and anti-T4 antibodies when added to the first culture. Probably the occurrence of direct interaction of Ia-like antigens on B cells and $\mathrm{T} 4$ antigens on $\mathrm{T}^{+}$cells is essential to B cell triggering and both of the antibodies might have blocked the interaction and consequently the activation of B cells. It is not clear from the results presented in this paper whether the interactions between $\mathrm{T} 4$ antigens and Ia-like antigens occurred between $T$ and $B$ cells, or whether anti-Ia antibodies acted on Ia-like antigens only on macrophages, but not on B cells, resulting in blocking the function of macrophages and subsequent activation of $T$ cells (36), whereby B cells failed to evolve into Igproducing cells. If the latter is the case, $T$ cells that have been individually prestimulated with PWM in the presence of monocytes could be activated, such that if individually prestimulated T and B cells are combined without PWM (first culture), the B cells should be rendered sensitive to $T$ cell-derived soluble factors during the first culture. However, such B cells from the first culture did not respond to exogenous $\mathrm{T}$ cell-derived soluble factors, so that these cells neither proliferated nor differentiated in the second culture (Fig. 3). Moreover, it has in general been known that $\mathrm{T}$ cell activation by mitogens, particularly PHA and Con A, requires the recognition of mitogens by the T3-Tin complexes as well as the recognition of Ia-like antigens on macrophages by the $\mathrm{T} 4$ antigens $(30,31)$. The results that anti-T3 antibodies did not block the B cell triggering by PWM (Fig. 5) indicate that the $\mathrm{T}$ cells that contact with PWM-stimulated B cells are not necessarily limited in activated cells but all that is necessary is for $\mathrm{T}^{+}$cells, either activated or unactivated, to recognize Ia-like antigens on B cells. Thus it is likely that the Ia-like antigens that $\mathrm{T} 4$ antigens recognize are, at least in part, those on B cells. It is known that anti-Ia antibodies can induce suppressor $\mathrm{T}$ cells (37) and that some activated $\mathrm{T}^{+}$cells function in the role of suppressor cells $(14,16,38)$. However, it is very unlikely that suppressor function by either $\mathrm{T}^{+}$or $\mathrm{T}^{+}$cells that might be generated in the first culture might be mediated by anti-Ia antibodies, because anti-Ia antibodies should have first activated either $\mathrm{T}^{+}$or $\mathrm{T}^{+}$cells and rendered the profound suppressor activity to these cells in the course of $6 \mathrm{~h}$ in the first culture. Moreover, these suppressor effector cells should have also inhibited the B cell triggering in the very same course of 6 $h$ in the first culture.

The effect of a series of monoclonal antibodies in the second culture was also investigated. Once B cells were triggered in the first culture, they proliferated and went on to differentiate into Ig-secreting cells in the second culture, regardless of the presence of anti-Ia, anti-T3, anti-T4, anti-T8, or anti-Tac antibody. IL2 receptors, Tac antigens, have been found to be expressed on B lymphocytes as well in recent years (39-41) and it has been documented that IL-2 exerts a direct effect on B cell function (41). As far as our results are concerned, Ig production was not inhibited even if anti-Tac antibodies were added to the second culture of PWM-activated B cells. Conceivable reasons for this phenomenon would be $(a)$ the possibility that BSF and BCDF as well as IL-2 would be enriched in our preparations of T cellderived soluble factors and that complementary proliferation and differentiation by BSF and BCDF would occur even though the proliferation through interactions of IL-2 and IL-2 receptors is impeded by anti-Tac antibodies and $(b)$ the possibility that B cell subsets activated by PWM would maturate in an IL-2-independent manner. Further study is now underway on this point. On the other hand, the fact that anti-Ia-like antibodies have no inhibitory effect in the second culture indicates that the responsiveness to $T$ cell-derived factors of $B$ cells that once have been activated and become sensitive to the factors could no longer be mediated by Ia-like antigens. Thus, the in vivo use of monoclonal antibodies to regulate immune responses, particularly activation steps of B cells, should require a careful evaluation to determine in which phase(s) of the activation cascade abnormal $B$ cells reside and the selection of proper monoclonal antibodies, depending on the phase in this cascade. We hope that our results will provide new and potentially important avenues of approach to the clinical use of monoclonal antibodies in the future.

\section{Acknowledgments}

We wish to thank Dr. T. Tsuchiya of Nihon University School of Medicine (Tokyo, Japan) and Dr. T. Uchiyama of Kyoto University School of Medicine (Kyoto, Japan) for providing SAC and anti-Tac antibody, respectively. We are indebted to Ms. $H$. Horii for help in preparing the manuscript.

This work was supported in part by grants in aid for scientific research, project Nos. 59480200 and 59770446 from the Ministry of Education, Science, and Culture of Japan.

\section{References}

1. Howie, S., and W. H. McBride. 1982. Cellular interactions in thymus-dependent antibody responses. In B Lymphocytes Today. J. R. Inglis, editor. Elsevier Biomedical Press, Amsterdam/New York/Oxford. $49-54$.

2. Julis, M. H. 1982. Cellular interactions in T-dependent B-cell activation. In B Lymphocytes Today. J. R. Inglis, editor. Elsevier Biomedical Press, Amsterdam/New York/Oxford. 55-58.

3. Niederhuber, J. E., and P. Allen. 1980. Role of I-region gene products in macrophage induction of an antibody response. II. Restriction at the level of $\mathrm{T}$ cell in recognition of I-J-subregion macrophage determinants. J. Exp. Med. 151:1103-1113.

4. Andersson, J., and F. Melchers. 1981. T cell dependent activation of resting B cells: requirement for both nonspecific unrestricted and antigen-specific Ia-restricted soluble factors. Proc. Natl. Acad. Sci. USA. 78:2497-2501.

5. Tite, J. P., J. Kaye, and B. Jones. 1984. The role of B cell surface Ia antigen recognition by $T$ cells in $B$ cell triggering: analysis of the interaction of cloned helper $\mathrm{T}$ cells with normal $\mathrm{B}$ cells in differing states 
of activation and with B cells expressing the xid defect. Eur. J. Immunol. 14:553-561.

6. Yoshizaki, K., T. Nakagawa, T. Kaieda, A. Muraguchi, Y. Yamamura, and T. Kishimoto. 1982. Induction of proliferation and Ig production in human $B$ leukemic cells by anti-immunoglobulins and $T$ cell factors. J. Immunol. 128:1296-1301.

7. Romagnani, S., M. G. Giudizi, R. Biagiotti, F. Almerigogna, E. Maggi, G. Del Prete, and M. Ricci. 1981. Surface immunoglobulins are involved in the interaction of protein A with human $B$ cells and in the triggering of B cell proliferation induced by protein A-containing Staphylococcus aureus. J. Immunol. 127:1307-1313.

8. Falkoff, R. J. W., L. P. Zhu, and A. S. Fauci. 1982. Separate signals for human B cell proliferation and differentiation in response to Staphylococcus aureus: evidence for a two-signal model of B cell activation. J. Immunol. 129:97-102.

9. Kishimoto, T., K. Yoshizaki, M. Kimoto, M. Okada, T. Kuritani, H. Kuritani, K. Shimizu, N. Nakagawa, Y. Miki, H. Kishi, K. Fukunaga, T. Yoshikubo, and T. Taka. 1984. B cell growth and differentiation factors and mechanism of B cell activation. Immunol. Rev. 78:97-118.

10. Muraguchi, A., J. H. Kehrl, J. L. Butler, and A. S. Fauci. 1984. Regulation of human B-cell activation, proliferation, and differentiation by soluble factors. J. Clin. Immunol. 4:337-347.

11. Keightley, R. G., M. D. Cooper, and A. R. Lawton. 1976. The $T$ cell dependence of $B$ cell differentiation induced by pokeweed mitogen. J. Immunol. 117:1538-1544.

12. Thomas, Y., J. Sosman, O. Irigoyen, L. Rogozinski, S. M. Friedman, and L. Chess. 1982. Immunoregulatory T cell interactions. In Human B-Lymphocyte Function: Activation and Immunoregulation. A. S. Fauci and R. E. Ballieux, editors. Raven Press, New York. 225-237.

13. Reinherz, E. L., and S. F. Schlossman. 1982. Human inducerand suppressor-T-cell-subset regulation of B-cell immunoglobulin production. In Human B Lymphocyte Function: Activation and Immunoregulation. A. S. Fauci and R. E. Ballieux, editors. Raven Press, New York. 201-212.

14. Kotani, H., S. Takada, Y. Ueda, Y. Murakawa, N. Suzuki, and T. Sakane. 1984. Activation of immune regulatory circuits among OKT4 ${ }^{+}$ cells by autologous mixed lymphocyte reactions. Clin. Exp. Immunol. 56:390-398.

15. Puck, J. M., and R. R. Rich. 1984. Regulatory interactions governing the proliferation of $\mathrm{T}$ cell subsets stimulated with pokeweed mitogen. J. Immunol. 132:1106-1112.

16. Takada, S., Y. Ueda, Y. Murakawa, N. Suzuki, and T. Sakane. 1983. Functional heterogeneities among concanavalin A-activated $\mathrm{OKT}^{+}$and $\mathrm{OKT}^{+}$cells by using autologous erythrocyte rosette technique. J. Clin. Invest. 72:2060-2071.

17. Murakawa, Y., S. Takada, Y. Ueda, N. Suzuki, T. Hoshino, and T. Sakane. 1985. Characterization of T lymphocyte subpopulations responsible for deficient interleukin 2 activity in patients with systemic lupus erythematosus. J. Immunol. 134:187-195.

18. Sakane, T., Y. Ueda, N. Suzuki, Y. Niwa, T. Hoshino, and T. Tsunematsu. 1985 . OKT4 ${ }^{+}$and $\mathrm{OKT}^{+} \mathrm{T}$ lymphocytes produce soluble factors that can modulate growth and differentiation of human B cells. Clin. Exp. Immunol. 62:112-120.

19. Mier, J. W., and R. C. Gallo. 1980. Purification and some characteristics of human T-cell growth factor from phytohemagglutininstimulated lymphocyte-conditioned media. Proc. Natl. Acad. Sci. USA. 77:6134-6138.

20. Ruscetti, F. W., and R. C. Gallo. 1981. Human T-lymphocyte growth factor: regulation of growth and function of T lymphocytes. Blood. 57:379-394.

21. Gronowicz, E., A. Coutinho, and S. F. Melcher. 1976. A plaque assay for all cells secreting Ig of a given type or class. Eur. J. Immunol. 6:588-590.

22. Waldman, T. A., and S. Broder. 1982. Polyclonal B-cell activators in the study of the regulation of immunoglobulin synthesis in the human system. Adv. Immunol. 32:1-63.

23. Reinherz, E. L., S. C. Meuer, and S. F. Schlossman. 1983. The delineation of antigen receptors on human T lymphocytes. Immunol. Today. 4:5-8.
24. Morimoto, C., E. L. Reinherz, Y. Borel, E. Mantzouranis, A. D. Steinberg, and S. F. Schlossman. 1981. Autoantibody to an immunoregulatory inducer population in patients with juvenile rheumatoid arthritis. J. Clin. Invest. 67:753-761.

25. Platsoucas, C. D., and R. A. Good. 1981. Inhibition of specific cell mediated cytotoxicity by monoclonal antibodies to human $\mathrm{T}$ cell antigens. Proc. Natl. Acad. Sci. USA. 78:4500-4504.

26. Engleman, E. G., C. J. Benike, C. Metzler, P. A. Gatenby, and R. L. Evans. 1983. Blocking of human T lymphocyte functions by antiLeu-2 and anti-Leu-3 antibodies: differential inhibition of proliferation and suppression. J. Immunol. 130:2623-2628.

27. Rogozinski, L., A. Bass, E. Glickman, M. A. Talle, G. Goldstein, L. Chess, and Y. Thomas. 1984. The T4 surface antigen is involved in the induction of helper function. J. Immunol. 132:735-739.

28. Delfraissy, J. F., A. Vazquez, C. Wallon, R. M. Desmottes, and P. Galanaud. 1984. Helper T cell activation for the human B-cell response to trinitrophenylated polyacrylamide beads: involvement of the T4 antigen. Eur. J. Immunol. 14:426-430.

29. Takada, S., Y. Ueda, N. Suzuki, Y. Murakawa, T. Hoshino, I. Green, A. D. Steinberg, D. A. Horwitz, and T. Sakane. 1985. Abnormalities in autologous mixed lymphocyte reaction-activated immunologic processes in systemic lupus erythematosus and their possible correction by interleukin 2. Eur. J. Immunol. 15:262-267.

30. van Wauwe, J. P., J. R. DeMey, and J. G. Goossens. 1980. OKT3: a monoclonal anti-human $\mathrm{T}$ lymphocyte antibody with potent mitogenic properties. J. Immunol. 124:2708-2713.

31. Landegren, U., J. Andersson, and H. Wigzell. 1984. Mechanism of T lymphocyte activation by OKT3 antibodies: a general model for T cell induction. Eur. J. Immunol. 14:325-328.

32. Reinherz, E. L., R. E. Hussey, and S. F. Schlossman. 1980. A monoclonal antibody blocking human $\mathrm{T}$ cell function. Eur. J. Immunol. 10:758-762.

33. Chang, T. W., P. C. Kung, S. P. Gingras, and G. Goldstein. 1981. Does OKT 3 monoclonal antibody react with antigen recognition structure on human T cells? Proc. Natl. Acad. Sci. USA. 78:1805-1808.

34. Niederhuber, J. E., J. A. Frelinger, E. Dugan, A. Coutinho, and D. C. Shreffler. 1975. Effects of anti-Ia serum on mitogenic responses. I. Inhibition of the proliferative response to B cell mitogen, LPS, by specific anti-Ia sera. J. Immunol. 115:1672-1676.

35. Yachie, A., T. Miyawaki, T. Yokoi, T. Nagaoki, and N. Taniguchi. 1982. Ia-positive cells generated by PWM-stimulation within OKT4 subset interact with OKT8 cells for inducing active suppression on B cell differentiation in vitro. J. Immunol. 129:103-106.

36. Geha, R. S., H. Milgrom, M. Broff, S. Alpert, S. Martin, and E. J. Yunis. 1979. Effect of anti-HLA antisera on macrophage-T cell interaction. Proc. Natl. Acad. Sci. USA. 76:4038-4041.

37. Broder, S., M. Megson, L. Muul, A. Muchmore, R. M. Blaese, and D. L. Mann. 1982. Activation of regulatory cells by antibodies to human Ia-like antigens. In Human B-Lymphocyte Function: Activation and Immunoregulation. A. S. Fauci and R. E. Ballieux, editors. Raven Press, New York. 289-297.

38. Sakane, T., H. Kotani, S. Takada, Y. Murakawa, and Y. Ueda. 1983. A defect in the suppressor circuits among OKT4 ${ }^{+}$cell populations in patients with systemic lupus erythematosus occurs independently of a defect in the $\mathrm{OKT}^{+}{ }^{+}$suppressor T cell function. J. Immunol. 131:753761.

39. Tsudo, M., T. Uchiyama, and H. Uchino. 1984. Expression of Tac antigen on activated normal human B cells. J. Exp. Med. 160:612617.

40. Waldmann, T. A., C. K. Goldman, R. J. Robb, J. M. Depper, W. J. Leonard, S. O. Sharrow, K. F. Bongiovanni, S. J. Korsmeyer, and W. C. Greene. 1984. Expression of interleukin 2 receptors on activated human B cells. J. Exp. Med. 160:1450-1466.

41. Muraguchi, A., J. H. Kehrl, D. L. Longo, D. J. Volkman, K. A. Smith, and A. S. Fauci. 1985. Interleukin 2 receptors on human B cells: implications for the role of interleukin 2 in human B cell function. $J$. Exp. Med. 161:181-197. 